\title{
THE RELATIONSHIP BETWEEN FAMILY HISTORY, CONSUMPTION OF FRUITS AND VEGETABLES, AND PHYSICAL ACTIVITY AND HYPERTENSION
}

\author{
Hubungan Riwayat Keluarga, Konsumsi Buah dan Sayur, dan Aktivitas Fisik dengan Kejadian Hipertensi
}

\section{Farida Syamsi}

Public Health Faculty, Universitas Airlangga, farida.syamsi-2015@fkm.unair.ac.id

Corresponding Author : Farida Syamsi, farida.syamsi-2015@fkm.unair.ac.id, Department of Epidemiology, Public Health Faculty, Univerisitas Airlangga, Dr. Ir. H. Soekarno Street, Mulyorejo, Surabaya City, East Java, Indonesia, Postal Code 60115

\section{ARTICLE INFO}

Received May 31 ${ }^{\text {st }}, 2019$

Revised form June, $21^{\text {st }}, 2019$

Accepted September, 26 ${ }^{\text {th }}, 2019$

Published online September, $30^{\text {th }}$,

2019

\section{Keywords:}

hypertension;

family history;

consumption of vegetables and

fruits;

physical activity

\section{Kata Kunci:}

hipertensi;

riwayat keluarga;

konsumsi sayur dan buah;

aktivitas fisik

\begin{abstract}
Background: The prevalence of hypertension in 2018 in Indonesia in people aged $\geq 18$ years was $34.11 \%$, an increasing trend compared to 2013, when it was $25.80 \%$. Malang Region increased the prevalence of hypertension from $7.32 \%$ in 2016 to $9 \%$ in 2017. Purpose: This study aims to analyse the relationship between hypertension and the variables of family history, consumption of fruit and vegetables, and physical activity in Integrated Guidance Post Wajak District, Malang Region. Methods: This study is an observational study with a crosssectional design. It used 2018 secondary data from P2PTM section of Provincial Health Agency of East Java. The total sample was 250 respondents in Integrated Guidance Post, Wajak District, Malang Regency. The independent variables were family history, consumption of fruit and vegetables, and physical activity, while the dependent variable was hypertension. Data were analysed using a chisquare test. Results: A significant relationship was found between the independent variables family history $(\mathrm{p}=0.01 ; \mathrm{PR}=2.01 ; 95 \% \mathrm{CI}=$ $1.21<\mathrm{PR}<3.34)$, consumption of fruit and vegetables $(\mathrm{p}=0.02 ; \mathrm{PR}$ $=1.89 ; 95 \% \mathrm{CI}=1.13<\mathrm{PR}<3.14)$, and physical activity $(\mathrm{p}=0.00$; $\mathrm{PR}=2.85 ; 95 \% \mathrm{CI}=1.70<\mathrm{PR}<4.77$ ) and the dependent variable of hypertension. Conclusion: There was a relationship between the independent variables of family history, lack of consumption of fruit and vegetables, and lack of physical activity and the dependent variable of hypertension.
\end{abstract}

C2019 Jurnal Berkala Epidemiologi. Published by Universitas Airlangga. This is an open access article under CC-BY-SA license (https://creativecommons.org/licenses/by-sa/4.0/)

\section{ABSTRAK}

Latar Belakang: Prevalensi kejadian hipertensi pada usia $\geq 18$ tahun di Indonesia mengalami peningkatan dari 25,80\% pada tahun 2013 menjadi $34,11 \%$ pada tahun 2018. Peningkatan prevalensi kejadian hipertensi terjadi di Kabupaten Malang dari 7,325 di tahun 2016 menjadi 9\% pada tahun 2017. Tujuan: Penelitian ini bertujuan untuk menganalisis hubungan antara riwayat keluarga, konsumsi buah dan sayur, dan aktivitas fisik dengan kejadian hipertensi di 
Posbindu Kecamatan Wajak, Kabupaten Malang tahun 2018. Metode: Penelitian ini merupakan penelitian observasional analitik dengan desain penelitian cross sectional. Penelitian ini menggunakan data sekunder dari seksi P2PTM Dinas Kesehatan Provinsi Jawa Timur tahun 2018. Penelitian ini menggunakan total sampling yaitu sejumlah 250 responden di Posbindu Kecamatan Wajak, Kabupaten Malang. Variabel bebas adalah riwayat keluarga, konsumsi buah dan sayur, dan aktivitas fisik, sedangkan variabel terikat adalah kejadian hipertensi. Analisis data yang digunakan yaitu uji Chi square untuk menganalisis hubungan antar variabel. Hasil: Penelitian ini menunjukkan terdapat hubungan antara riwayat keluarga $(p=0,01$; $P R=2,01 ; 95 \% C I=1,21<P R<3,34)$, konsumsi buah dan sayur $(p=0,02 ; P R=1,89 ; 95 \% C I=1,13<P R<3,14)$, dan aktivitas fisik ( $p=0,00 ; P R=2,85 ; 95 \% C I=1,70<P R<4,77)$ terhadap kejadian hipertensi. Kesimpulan: Kurang aktifitas fisik dan adanya riwayat keluarga meningkatkan kejadian hipertensi, sebaliknya konsumsi buah dan sayur dapat menurunkan kejadian hipertensi.

(C2019 Jurnal Berkala Epidemiologi. Penerbit Universitas Airlangga. Jurnal ini dapat diakses secara terbuka dan memiliki lisensi CC-BY-SA (https://creativecommons.org/licenses/by-sa/4.0/)

\section{INTRODUCTION}

Non-communicable diseases (NCD) such as cardiovascular disease cause many deaths worldwide. They are referred to as 'silent killers', as no symptoms show in the initial phase of the disease. In 2012, cases of death caused by cardiovascular disease reached 9.40 million, the majority of which were caused by hypertension (WHO, 2014).

The World Health Organization (WHO) found that $75 \%$ of the world population suffers from hypertension; $40 \%$ of these cases come from developing countries and $35 \%$ from advanced countries. The highest percentage of people with hypertension is in the African region with $46 \%$. The percentage of adults with hypertension in the Southeast Asia region is $36 \%$ and 1.50 million sufferers die each year. Nowadays, more than $25 \%$ of the word population suffers from hypertension. This percentage will continue to increase and is predicted to reach 1.15 billion, or around $29 \%$, by 2025 (WHO, 2014).

Based on Indonesia's basic health research (Riskesdas) in 2018, it is suggested that hypertension, based on measurements among residents aged $\geq 18$ years, was $34.11 \%$. This number has increased by $8.31 \%$ compared to 2013 . The proportion of female hypertension patients $(36.85 \%)$ is higher than male patients. The prevalence of hypertension has increased along with age; the highest prevalence of hypertension is
$>75$ years old (69.53\%) (Ministry of Health RI, 2018a).

The percentage of hypertension in the East Java Province is $20.43 \%$ or around $1,828,669$ cases. The proportion of males is higher than females, with $20.83 \%$ or around 825,412 cases (Ministry of Health RI, 2018b). The prevalence of hypertension in Malang Regency in 2016 was $7.32 \%$. This number increased by $1.68 \%$ to $9 \%$ in 2017 (East Java Provincial Health Office, 2018).

Hypertension is a complex condition, where blood pressure is permanently above the normal level, causing nutrients and oxygen intake in the body, which should be transported by the blood to the body's tissues that need it, to become clogged. The criteria for hypertension refer to the diagnostic criteria presented by the Joint National Committee (JNC) VII, which is when the blood pressure measurement is $\geq 140 / 90 \mathrm{mmHg}$ (Ministry of Health RI, 2018a).

Complications in patients with hypertension are due to blood pressure that is constantly above normal over a long period. This causes disruptions to brain tissue and blood vessels, causing disease such as coronary heart disease, kidney failure, or stroke, and leading to death (Putriastuti, 2016).

Risk factors for hypertension are divided into non-modifiable factors such as age, sex, and family history of hypertension, while modifiable factors are smoking, alcohol consumption, physical activity, consumption of fruit and vegetables, and excessive salt consumption. These risk factors, if not managed properly, will cause 
physiological changes in the body, which can result in obesity and increases in blood cholesterol, blood sugar, and blood pressure (Riley et al., 2016).

Increased blood pressure is also caused by a family history, due to interaction between genes and the environment (Dedullah, Malonda, \& Joseph, 2015). When the genetic inheritance of essential hypertension is left without precautionary measures, the body will develop over the next 3050 years the symptoms of hypertension (Mohd Arifin, Weta, \& Ratnawati, 2016).

The proportion of the Indonesian population who do not have adequate consumption of fruit and vegetables at the age of $\geq 5$ years, based on the results of the 2018 Riskesdas, is $93.90 \%$ (Ministry of Health RI, 2018a). Increased blood pressure can be caused by low potassium intake and stimulation of renin secretion due to high sodium levels. This may cause peripheral blood vessel constriction (Anwar, 2014).

Data from health research in 2018 showed that the proportion of the population aged $\geq 10$ years who lacked sufficient physical activity was $33.50 \%$ (Ministry of Health RI, 2018a). Blood vessels become more elastic and the heart's performance more efficient when people conduct regular and active physical activity, resulting in a decrease in blood pressure (Aryantiningsih \& Silaen, 2018).

Malang Regency was chosen in 2018 to carry out the periodic health screening related to early NCD risk factors through the Integrated Guidance Post for Non-Communicable Diseases, targeting the population aged 15 years and over, in the hope that the health screening would be able to maximise the performance of Integrated Guidance Post in Wajak District of Malang Regency. Malang also has a Smart Health programme which is supported by the United Kingdom and Brawijaya University (Maharani et al., 2019).

Previous studies have shown that many people with hypertension have one or more risk factors that may cause hypertension, especially for the modifiable factors. This study was conducted with the purpose of analysing the relationship between hypertension and the factors of family history, consumption of fruit and vegetables, and physical activity in Integrated Guidance Post Wajak District, Malang Regency in 2018.

\section{METHODS}

This study is an observational study with a cross-sectional design. The population are people from Wajak, Blayu, Sukolilo, Sukoanyar, and Kidangbang villages, Wajak District, Malang Regency. This study used a total sample of 250 respondents, using secondary data from P2PTM Provincial Health Agency of East Java in 2018.

The variables for this study are independent variables consisting of family history, consumption of fruit and vegetables, and physical activity, while the dependent variable is hypertension. The age variables are categorized into six categories, $17-25,26-35,36-45,46-55$, $56-65$, and $\geq 65$ years old. The family history variable is categorised as 'Yes' if the respondent has a history of hypertension from one or both biological parents. The variable consumption of fruit and vegetables is included in the 'adequate' category if the respondent consumes at least five servings of fruit and vegetables every day in one week. The physical activity variable is categorised as 'adequate' if the respondent routinely conducts physical activities at least 30 minutes per day. The respondents are categorised as having hypertension if their blood pressure is $\geq 140 / 90$ $\mathrm{mmHg}$ (Ministry of Health RI, 2018a).

The data collected were then processed and analysed, using univariable analysis and bivariable analysis. Univariable analysis describes variables in the form of frequency distribution, while bivariable analysis is an analysis of the relationship between variables using the chi-square statistical test with significance level of 0.05 . The entire process of data processing and analysis was conducted through the SPSS program.

\section{RESULTS}

The majority of respondents were aged $46-55$ years $(26.80 \%)$, a large majority were female $(81.60 \%)$, and most had an elementary school education (45.60\%) (Table 1).

\section{Relationship between Family History and Hypertension}

Table 2 shows that the majority of hypertension patients with a family history of hypertension is $60.00 \%$. The results of the chisquare test show that $\mathrm{p}=0.01(\mathrm{p}<0.05)$, which means there is a significant relationship between family history and hypertension. The calculation results of $\mathrm{PR}=2.01(95 \% \mathrm{CI}=1.21<\mathrm{PR}<3.34)$ means respondents with a family history of hypertension are 2.01 times more likely to be at risk of hypertension than respondents without a family history of hypertension. 
Table 1

Distribution of Respondents' Characteristics in Integrated Guidance Post Wajak District in 2018

\begin{tabular}{lrr}
\hline \multicolumn{1}{c}{ Characteristic } & $\mathrm{n}$ & \multicolumn{1}{c}{$\%$} \\
\hline Age (Years Old) & 9 & 3,60 \\
$17-25$ & 37 & 14,80 \\
$26-35$ & 57 & 22,80 \\
$36-45$ & 67 & 26,80 \\
$46-55$ & 58 & 23,20 \\
$56-65$ & 22 & 8,80 \\
$>65$ & & \\
Sex & 46 & 18,40 \\
Male & 204 & 81,60 \\
Female & & \\
Level of Education & 3 & 1,20 \\
Uneducated & 114 & 45,60 \\
Elementary Graduate & 54 & 21,60 \\
Middle School Graduate & 60 & 24,00 \\
High School Graduate & 19 & 7,60 \\
College Graduate & 250 & 100,00 \\
\hline Total & 2018 & \\
\hline Source: East Java Provincial Health Office
\end{tabular}

\section{Relationship between Fruit and Vegetable Consumption and Hypertension}

Table 2 shows the relationship between hypertension cases and low consumption of fruit and vegetables $(52.86 \%)$. The results of the chisquare test show that $p=0.02(p<0.05)$, which means that there is a significant relationship between fruit and vegetable consumption and hypertension. The calculation results of $\mathrm{PR}=1.89$ $(95 \% \mathrm{CI}=1.13<\mathrm{PR}<3.14)$ means respondents with low consumption of fruit and vegetables are
11.89 times more likely to be at risk of hypertension than respondents with adequate consumption of fruit and vegetables.

\section{Relationship between Physical Activity and Hypertension}

Table 2 shows that the majority of hypertension is found in respondents who lack physical activity $(62.86 \%)$. The results of the chisquare test showed that $\mathrm{p}=0.00(\mathrm{p}<0.05)$, which means that there is a significant relationship between physical activity and hypertension. The calculation results of $\mathrm{PR}=2.85(95 \% \mathrm{CI}=1.70<$ $\mathrm{PR}<4.77)$, which means that respondents with lack of physical activity are 2.85 times more likely to be at risk of hypertension than respondents who do have adequate physical activity.

\section{DISCUSSION}

\section{Relationship between Age and Hypertension}

The majority of hypertension patients are 4655 years old. Individuals > 40 years old will experience a condition where the walls of blood vessels lose their elasticity. This can lead to increased blood pressure because the blood continues to pump without the presence of blood vessel dilatation (Tular, Ratag, \& Kandou, 2017). Hypertension may occur along with age. Hypertension is degenerative and is a disease that appears slowly, along with age, for years, thus patients may experience complications (Siervo et al., 2015).

\section{Table 2}

Chi Square Statistics Test Results between Family History, Fruit and Vegetable Consumption, and Physical Activity and Hypertension in Integrated Guidance Post of Wajak District in 2018

\begin{tabular}{|c|c|c|c|c|c|c|c|c|}
\hline \multirow{3}{*}{ Variable } & \multicolumn{4}{|c|}{ Hypertension } & \multirow{2}{*}{\multicolumn{2}{|c|}{ Total }} & \multirow{3}{*}{$p$} & \multirow{3}{*}{$\begin{array}{l}\text { PR Value } \\
(95 \% \text { CI) }\end{array}$} \\
\hline & \multicolumn{2}{|c|}{ Yes } & \multicolumn{2}{|c|}{ No } & & & & \\
\hline & $\mathrm{n}$ & $\%$ & $\mathrm{n}$ & $\%$ & $\mathrm{n}$ & $\%$ & & \\
\hline \multicolumn{9}{|c|}{ Family History } \\
\hline $\mathrm{Ya}$ & 84 & 60,00 & 47 & 42,73 & 131 & 52,40 & \multirow[t]{2}{*}{0,01} & 2,01 \\
\hline Tidak & 56 & 40,00 & 63 & 57.27 & 119 & 47,60 & & $(1,21<\mathrm{PR}<3,34)$ \\
\hline \multicolumn{9}{|c|}{ Fruit \& Vegetables Consumption } \\
\hline Inadequate & 74 & 52,86 & 41 & 37,27 & 115 & 46,00 & \multirow[t]{2}{*}{0,02} & 1,89 \\
\hline Adequate & 66 & 47,14 & 69 & 62,73 & 135 & 54,00 & & $(1,13<\mathrm{PR}<3,14)$ \\
\hline \multicolumn{9}{|c|}{ Physical Activity } \\
\hline Inadequate & 88 & 62,86 & 41 & 37,27 & 129 & 51,60 & \multirow[t]{2}{*}{0,00} & 2,85 \\
\hline Adequate & 52 & 37,14 & 69 & 62,73 & 121 & 48,40 & & $(1,70<\mathrm{PR}<4,77)$ \\
\hline Total & 140 & 100,00 & 110 & 100,00 & 250 & 100,00 & & \\
\hline
\end{tabular}

Source: East Java Provincial Health Office, 2018 
Hypertension can be influenced by a person's age. The risk increases along with the age of a person, although younger people are also at risk of hypertension. Aging can result in physiological changes in the body, one of which can cause a build-up of collagen elements in the muscle layer, which triggers the thickening of the arterial wall, resulting in stiffness and narrowing of the arteries (Rusnoto \& Setyono, 2018). This is in line with the study of Putriastuti (2016), which showed that the incidence of hypertension was found to be highest in people age $45-59$ years old (52.80\%).

\section{Relationship between Gender and Hypertension}

The majority of hypertension sufferers are women. This result is in line with Putriastuti (2016), who demonstrated that women are dominant in the occurrence of hypertension compared to men. The oestrogen hormone can increase the level of HDL (high density of lipoprotein), which hinders the occurrence of atherosclerosis. This continues to occur as women get older, and naturally decreases in women aged $45-55$ years old. This is what causes older women to be more vulnerable (Kishore, Gupta, Kohli, \& Kumar, 2016).

However, the result of this study is not in line with the research of Louisa, Sulistiyani, \& Joko (2018), which shows that hypertension is mostly found in men, because of work problems combined with smoking behaviour and alcohol consumption, compounded by bad diet and unhealthy lifestyle. This is what causes blood pressure in men to be higher than women. Hypertension is often found in men aged 35-65 years old who smoke (Rohkuswara \& Syarif, 2017).

\section{Relationship between the Level of Education and Hypertension}

The majority of the respondents were elementary school graduates. Education level is related to the level of knowledge. The result of the study is in line with Putriastuti (2016), whose study stated that the majority of respondents did not complete elementary school (25\%). The low level of education tends to encourage a lower level of knowledge about health. This is due to the difficulty of absorbing information from electronic and printed media.

Someone with a higher education level will have a higher level of knowledge regarding health problems, which means they can know and understand strategies for preventing the occurrence of disease. Different lifestyles can be caused by differences in education; thus the use of health services also differs for each person (Memah, Kandou, \& Nelwan, 2019).

\section{Relationship between Family History and Hypertension}

The analysis shows that there is a relationship between family history and hypertension. In line with research by Dedullah, Malonda, \& Joseph (2015), it is revealed that genetic factors increase the risk of hypertension, especially essential hypertension. Genetic factors are associated with other environmental factors, resulting in hypertension. The process of salt regulation and cell membrane renin is also related to genetic factors that exist in the body (Adam, Nelwan, \& Wariki, 2018).

The results of this study are also supported by Agustina \& Raharjo (2015), who revealed that if biological parents had hypertension, then there would be a $45 \%$ chance that it would be passed on to their offspring, and if only one parent had hypertension then the possibility would be $30 \%$ that it would be passed on to the offspring. Blood pressure in parents can influence the blood pressure of their biological children (Ranasinghe, Cooray, Jayawardena, \& Katulanda, 2015). The role of genetics certainly plays an important role in determining blood pressure. Someone who has monozygotic twins, if one of the twins has hypertension, it can increase the risk of hypertension caused by genetic makeup (Mohd Arifin et al., 2016).

\section{Relationship between Fruit and Vegetable Consumption and Hypertension}

The results of the analysis found that there is a relationship between fruit and vegetable consumption and hypertension. This is in line with Anwar's (2014) study, which revealed that an increase in blood pressure can be caused by obesity that occurs due to a low-fibre diet. The habit of someone who rarely consumes vegetables and fruit will have an impact on the body. Over time it will result in an increase in blood pressure, which is affected by an increase in vasoconstrictor hormones and lipids (Guwatudde et al., 2015).

Increased blood pressure can be caused by low potassium intake. The potassium mechanism works to protect blood vessels so that they remain elastic and non-constricted and are not quickly damaged due to high blood pressure in the body (Kurniasih, Pangestuti, \& Aruben, 2017). Blood pressure regulation is affected by the presence of sodium and potassium in the body to maintain the 
electrolytes, body fluids, and acid-base balance. High sodium levels can increase blood pressure (Gultom, Aritonang, \& Sudaryati, 2016). An increase in intracellular fluid concentration is caused by the amount of potassium consumption, which plays a role in maintaining osmotic pressure. Extracellular fluid will tend to be pulled, thus blood pressure decreases (Bertalina \& Muliani, 2018).

\section{Relationship between Physical Activity and Hypertension}

The results of analysis found that there is a relationship between the lack of physical activity and hypertension. The results are in line with Rihiantoro \& Widodo (2017), who revealed that hypertension is related to physical activity. Increased function and performance of blood vessels, lungs, and heart are characterised by a decline in the risk of atherosclerosis, an increase in HDL cholesterol, a decline in lactic acid accumulation, and stabilized heartbeat.

The incidence of hypertension is affected by physical activity. Individuals who have less physical activity will cause the heart muscle to work harder than normal conditions when a contraction occurs; therefore the heart rate has a higher frequency with hypertension sufferers than with normal people in general. The increased pressure is imposed on the arteries, where the heart muscle must pump more often and harder than usual (Aryantiningsih \& Silaen, 2018).

The results are in line with Guwatudde et al (2015), who suggested hypertension is more common among respondents with a lower level of physical activity. A decrease in blood pressure in a person's body may occur due to an increase in the endurance of the lungs and heart by conducting active physical activities routinely; hence the blood vessels remain elastic. Physical activity has a number of positive impacts and one does not have to spend intense time of one hour each day to benefit from exercise or physical activity. Brisk walking for 20-30 minutes each day is also very good. The principle of physical activity is to be measurable and stable, which is expected to maintain stability and fitness for each individual, which can have an impact on blood pressure in the body (Sriani, Fakhriadi, \& Rosadi, 2016).

\section{Research Limitation}

The data were obtained through questionnaires from secondary data. The method of questionnaires has limitations, namely it was unable to dig up information related to variables that had been examined thoroughly.

\section{CONCLUSION}

Hypertension may occur in people from various backgrounds. Hypertension relates to risk factors in each individual. These risk factors are family history, lack of physical activity, and lack of fruit and vegetable consumption. People with a family history of hypertension, low physical activity, and poor consumption of fruit and vegetables are at greater risk of hypertension.

\section{ACKNOWLEDGEMENT}

The author thanks the P2PTM section of Provincial Health Agency of East Java for providing the data, and all parties who offered support in the preparation of this scientific article

\section{REFERENCES}

Adam, A. G. A., Nelwan, J. E., \& Wariki, W. M. . (2018). The incidence of hypertension and family history of suffering from hypertension at the Paceda Health Centre, Bitung City. Jurnal Kesmas, 7(5), 1-5.

Agustina, R., \& Raharjo, B. B. (2015). Risk factors associated with the incidence of hypertension in productive age (25-54 years). Unnes Journal of Public Health, 4(4), 146158. https://doi.org/10.15294/ujph.v4i4.9690

Anwar, R. (2014). Fruit, vegetable, and milk consumption as risk factors for hypertension at the S. Parman Health Center in Banjarmasin. Jurnal Skala Kesehatan, 5(1), $1-8$.

Aryantiningsih, D. S., \& Silaen, J. B. (2018). Hypertension in the community of the Harapan Raya Puskesmas Pekanbaru. Jurnal Ipteks Terapan, 12(1), 64-77. https://doi.org/10.22216/jit.2018.v12i1.1483

Bertalina, \& Muliani. (2018). The relationship between diet, food intake, and central obesity with hypertension at the Rajabasa Indah Health Center in Bandar Lampung. Jurnal Kesehatan, 7(1), 34-45. https://doi.org/10.26630/jk.v7i1.116

Dedullah, R. F., Malonda, N. S. H., \& Joseph, W. B. S. (2015). The relationship between hypertension risk factors and the incidence of hypertension in the community in Motoboi Kecil Village, South Kotamobagu District 
Kotamobagu City. Jurnal Kesmas, 4(2), 111118.

East Java Provincial Health Office. (2018). East Java Province health profile in 2017. East Java Provincial Health Office. Surabaya.

Gultom, I. L., Aritonang, E. Y., \& Sudaryati, E. (2016). The relationship of food consumption with the incidence of hypertension in the elderly in Mekar Bahalat Village, Java Maraja Bah Jambi District, Simalungun Regency in 2016. Gizi, Kesehatan Reproduksi, dan Epidemiologi, 2(1), 1-10.

Guwatudde, D., Mutungi, G., Wesonga, R., Kajjura, R., Kasule, H., Muwonge, J., ... Bahendeka, S. K. (2015). The epidemiology of hypertension in Uganda: Findings from the national non-communicable diseases risk factor survey. PLoS ONE, 10(9), 1-13. https://doi.org/10.1371/journal.pone.0138991

Kishore, J., Gupta, N., Kohli, C., \& Kumar, N. (2016). Prevalence of hypertension and determination of its risk factors in Rural Delhi. International Journal of Hypertension, 34(7962595), $1-6$. https://doi.org/10.1097/01.hjh.0000501226.6 $1792.4 \mathrm{~b}$

Kurniasih, D., Pangestuti, D. R., \& Aruben, R. (2017). The relationship of sodium, magnesium, potassium, caffeine consumption, smoking habits and physical activity with hypertension in the elderly (study in the village of Puskesmas Duren Semarang Regency in 2017). Jurnal Kesehatan Masyarakat (e-Journal), 5(4), 629-639.

Louisa, M., Sulistiyani, \& Joko, T. (2018). The relationship of the use of pesticides with the incidence of hypertension in rice farmers in Gringsing Village, Gringsing District, Batang Regency. Jurnal Kesehatan Masyarakat (eJournal), 6(1), 654-661.

Maharani, A., Sujarwoto, Praveen, D., Oceandy, D., Tampubolon, G., \& Patel, A. (2019). Cardiovascular disease risk factor prevalence and estimated 10-year cardiovascular risk scores in Indonesia: the SMARThealth extend study. PLOS ONE, 14(4), 1-13. https://doi.org/10.1371/journal.pone.0215219

Memah, M., Kandou, G. D., \& Nelwan, J. E. (2019). The relationship between smoking habits and alcohol consumption with the incidence of hypertension in Puskesmas Kombi, Kombi Subdistrict, Minahasa Regency. Jurnal Kesmas, 8(1), 68-74.

Ministry of Health RI. (2018a). The main results of basic health research (Riskesdas) in 2018. Ministry of Health RI. Jakarta.

Ministry of Health RI. (2018b). Indonesia's health profile in 2017. Ministry of Health RI. Jakarta.

Mohd Arifin, M. H., Weta, I. W., \& Ratnawati, N. L. K. A. (2016). Factors related to the incidence of hypertension in the elderly in the working area of the UPT Petang I Health Centre in Badung Regency 2016. E-Jurnal Medika, 5(7), 1-23.

Putriastuti, L. (2016). Analysis of the relationship between exercise habits and the incidence of hypertension in patients aged more than 45 years. Jurnal Berkala Epidemiologi, 4(2), 225-236. https://doi.org/10.20473/jbe.v4i2.2016.225

Ranasinghe, P., Cooray, D. N., Jayawardena, R., \& Katulanda, P. (2015). The influence of family history of hypertension on disease prevalence and associated metabolic risk factors among Sri Lankan adults. BMC Public Health, 15(1), 1-9. https://doi.org/10.1186/s12889015-1927-7

Rihiantoro, T., \& Widodo, M. (2017). The relationship between diet and physical activity with the incidence of hypertension in Tulang Bawang Regency. Jurnal Keperawatan, 13(2), 159-167.

Riley, L., Guthold, R., Cowan, M., Savin, S., Bhatti, L., Armstrong, T., \& Bonita, R. (2016). The world health organization STEPwise approach to noncommunicable disease risk-factor surveillance: methods, challenges, and opportunities. American Journal of Public Health, 106(1), 74-78. https://doi.org/10.2105/AJPH.2015.302962

Rohkuswara, T. D., \& Syarif, S. P. (2017). The relationship obetween obesity with incidence of hypertension stage 1 at integrated coaching post of non-communicable disease (Posbindu PTM) Port Health Office of Bandung in 2016. Jurnal Epidemiologi Kesehatan Indonesia, 1(2), 13-18.

Rusnoto, \& Setyono, D. F. (2018). Relationship of hypercholesterolemia, obesity and family history of hypertension with the incidence of hypertension in the village of Megawon Kudus. Jurnal Ilmu Keperawatn dan Kebidanan, 9(1), 31-36.

Siervo, M., Lara, J., Chowdhury, S., Ashor, A., Oggioni, C., \& Mathers, J. C. (2015). Effects of the dietary approach to stop hypertension (DASH) diet on cardiovascular risk factors: a systematic review and meta-analysis. British 
Journal of Nutrition, 113(1), 1-15. https://doi.org/10.1017/S0007114514003341

Sriani, K. I., Fakhriadi, R., \& Rosadi, D. (2016). The relationship between smoking behavior and exercise habits with the incidence of hypertension in men aged 18-44 years. Jurnal Publikasi Kesehatan Masyarakat Indonesia, 3(1), 1-6.

Tular, G. J., Ratag, B. T., \& Kandou, G. D. (2017). The relationship between physical activity, family history and age with the incidence of hypertension in Tarabitan Village, West Likupang District, North Minahasa Regency. Media Kesehatan, 9(3), 1-6.

WHO. (2014). Global status report on noncommunicable diseases 2014. World Health Organization. Geneva. 